\title{
ÚLOHA SESTRY V PROSTREDÍ ŠKOLY
}

\author{
L'uboslava Pavelová, Erika Krištofová, Jozefína Mesárošová, Andrea Solgajová \\ Katedra ošetrovatel'stva FSVaZ UKF Nitra \\ lpavelova2@ukf.sk, ekristofova@ukf.sk, jmeszarosova@ukf.sk
}

\begin{abstract}
Abstrakt: Ciel'om výskumu bolo zistit' stanovisko žiakov k zdravotno-výchovným aktivitám v oblasti zdravia, manželstva, rodičovstva a sexuálnej výchovy. Zistit’ postoj žiakov a pedagógov základnej školy na úlohu sestry v školskom prostredí, jej kompetencie, spoluprácu s inými odborníkmi. Neštandardizovaný dotazník vlastnej konštrukcie bol predložený 284 respondentom. Do prvej výskumnej vzorky bolo zaradených 219 žiakov vo veku 10-14 rokov, do druhej 65 pedagógov základnej školy. Na posúdenie vzájomných vzt'ahov medzi odpoved'ami sa použil dvojvýberový t-test a Chí-kvadrát test nezávislostí. Sociálne siete a priatelia boli pre žiakov výraznými zdrojmi získavania informácií a školskú sestru pokladali za nezávislého, vhodného odborníka pre realizáciu zdravotnej výchovy. Žiaci aj pedagógovia mali pozitívny postoj k implementácii pracovnej pozície školskej sestry, ale pozorované rozdiely neboli štatisticky významné (hladina významnosti $\alpha=0,05, \chi^{2}=2,58, p=0,108$, ). Pedagógovia spoluprácu so školskou sestrou považovali za významnú a to najmä v prevencii úrazov, aplikácii liekov chronicky chorým det’om, aktivitám zameraným na emocionálnu podporu zdravia žiakov a sexuálnu výchovu však považovali za málo významnú. Dievčatá ako najvýraznejšiu úlohu školskej sestry označili edukáciu a poradenstvo v zdravom stravovaní $(\mathrm{M}=2,8)$ a chlapci najviac sexuálnu výchovu $(M=2,5)$ a prevenciu závislostí. Štúdia podporila význam pozície školskej sestry v prostredí školy, pre žiakov v staršom školskom veku aj v oblasti sexuálnej výchovy. Pedagógovia zastali význam jej pozíciu v edukačných aktivitách zameraných na v oblasti všeobecnej zdravotno-výchovnej prevencie.
\end{abstract}

Kl'účové slová: Sestra. Základná škola. Ošetrovatel'stvo. Zdravotná výchova. Sexuálna výchova.

\section{ÚVOD}

Reprodukčné zdravie treba považovat' za bohatstvo každého národa a každý štát má preto povinnost' ho chránit'. Je ohrozované $\mathrm{v}$ rôznych fázach života rôznymi faktormi, sexuálnym zneužívaním v najmladšom veku, pohlavne prenosnými infekciami, neželanými tehotenstvami, rizikom nebezpečných, ilegálnych potratov, nútenou prostitúciou, materskou úmrtnost'ou, onkologickými ochoreniami pohlavných orgánov a špecifickými problémami pohlavných orgánov v séniu (Kliment, 2013). Podl'a Lukšíka a Bianchi (1996) je na Slovensku sexuálne správanie detí rizikovejšie a úroveň vzdelávania v oblasti sexuality výrazne nižšia ako vo vyspelých krajinách. Popper, Bianchi, Lukšík, Supeková, Ingham (2005) poukazujú na nižšiu (až žiadnu) mieru komunikácie o sexualite v rodinách. Absenciu poznatkov mladí l’udia nahrádzajú komunikáciou medzi vrstovníkmi. Sexuálne aktívni mladí l'udia na Slovensku v menšej miere zvažujú riziká a rozprávajú o rizikách tehotenstva. Takisto menej používajú kondóm a antikoncepciu. Helfferich, Heidtke (2006) uvádzajú, že v každom období života diet’at’a sa objavujú špecifické problémy. Stredný a starší školský vek zahrňuje obdobie prudkých telesných aj psychických zmien zapríčinených pohlavným dozrievaním - pubertou. Ide o obdobie od 10-12. roku do 15-17. roku, v ktorom sa dovŕši telesné dospievanie. Intenzita, začiatok aj koniec puberty je u jednotlivých deti vel’mi odlišná. Deti majú vlastnú sexualitu a čast' ich predstáv, aktivít a komunikácie je zviazaná so 
sexualitou. Baker et al. (2003) odporúčajú na základe princípov Svetovej zdravotníckej organizácie, aby deti mali adekvátne informácie pre ich ochranu pred sexuálnym zneužívaním, pohlavne prenosnými infekciami, neželaným tehotenstvám, ktoré im v primeranej podobe má zabezpečit' štátny vzdelávací systém formou sexuálnej výchovy a starostlivosti o sexuálne zdravie a výchovu $\mathrm{k}$ rodičovstvu. Každé diet’a, mladý človek v Európe by mal mat' príležitost' na vzdelanie v škole podporujúcej zdravie. Po vzniku nového usporiadania v Európe bol tento program prijatý aj na Slovensku a v Čechách. Prispieva k osvojeniu si zdravého spôsobu života, k pestovaniu väčšej zodpovednosti za vlastné zdravie a schopnosti zvládnut’ základné rizikové faktory ohrozujúce zdravie a predchádzat’ tak ochoreniam (Havlínová et al., 2006).

Kliment (2013) uvádza, že v krajinách kde je zavedená povinná sexuálna výchova je neskorší štart sexuálneho života, nižší výskyt potratov a tehotenstiev tínedžerov, ako aj nižší výskyt sexuálne prenosných infekcií. Kliment (2013) zastáva názor, „deti nevedia, že existujú sexuálne prenosné infekcie asexuálne zneužívanie a nevedia, ako sa k problému postavit' ako pri objavení sa tohto rizika komunikovat's dospelými. Namiesto toho majú pocity viny. Najmladšia veková skupina dievčat je najviac ohrozená nútenou prostitúciou a neželaným tehotenstvom a štát ich ponecháva $v$ zmätku $v$ súvislosti s rozdielnymi informáciami, ktoré získavajú v rámci liberálnejšej etickej a konzervatívnej náboženskej výchovy. Pokial' by sa problémy v tejto oblasti riešili komplexne a nie živelne, nevznikali by situácie, ktoré práve absencia štátnej politiky vytvára pre ženy v zložitých životných situáciách".

Základy sexuálnej výchovy diet'at’a musí garantovat' rodina. Podla Ráškovej (2013) „len dobre fungujúca rodina poskytuje diet'at'u potrebnú dávku citového zázemia a poskytuje mu dôležité životné vzory“. Prostredie základnej a strednej školy sa javí ako optimálny prostriedok na dosiahnutie spoločných ciel'ov v tejto oblasti. Rašková (2013) kladie otázku, či je pedagóg kompetentným odborníkom, ktorý pri sexuálnej výchove detí disponuje odbornými znalost'ami, schopnost’ami i osobnostnými predpokladmi.

Charta sexuálnych a reprodukčných práv prijatá v roku 1995 v dvanástich ciel'och formuluje podporu a ochranu sexuálnych a reprodukčných práv a slobôd vo všetkých politických, ekonomických a kultúrnych systémoch sveta. Uvádza, že nemožno jej realizáciu ponechat' len na slobodnej vol'be rodiny, nie je možné zaručit', že v nej diet'a bude získavat' (pokial' nebude tabuizovaná) subjektívne aj spoločensky žiaduce vedomosti, postoje a správanie z najširšej oblasti sexuálneho správania (Definitions and Indicators in Family Planning, 1999). Jednou zo základných funkcií spoločnosti je výchova, vzdelávanie detí v školách. Pre zdravý duševný, telesný a sociálny vývin má významný vplyv prostredie školy. Sexuálna výchova v podmienkach vzdelávania detí na Slovensku vychádza $\mathrm{z}$ učebných osnov výchovy k manželstvu a rodičovstvu. Jej ciel'om je „utváranie základných vedomostí a zodpovedných postojov v oblasti partnerských vzt'ahov a rodičovstva v súlade s vedeckými poznatkami a etickými normami“ (Rovňanová, Lukšík, Lukšíková, 2007). Sielert (1994) uvádza, že orientácia školskej sexuálnej výchovy sa musí primerane opierat’ o základný konsenzus spoločnosti v oblasti sebaurčenia detí, úcte k dôstojnosti blížneho a podpore v spolunažívaní.

Podl'a Ráškovej (2013) „sexuálnu výchovu treba chápat’v intenciách pedagogicko-psychologických, pretože objektom výchovy je celá osobnost' diet'at'a pre jeho sociálne a sociálno sexuálne fungovanie $v$ partnerstve, manželstvo, rodičovstvo aj medzil'udských vzt'ahoch všeobecne“. Edukačný proces musí byt' vyvážený etickou, vzt'ahovou, sociálnou, emocionálnou a biologickou zložkou. Z tohto dôvodu nie je možné spájat' sexuálnu výchovu u detí v školskom období len v biologických intenciách, ktoré sú jednostranne zamerané najčastejšie na anatómiu a fyziológiu človeka, starostlivost' o svoje telo, problematiku HIV a AIDS a iné. V minulosti školskú zdravotnú službu určovala koncepcia odboru pediatrie, ktorú realizovali detskí lekári a sestry. „Náplňou práce bolo tiež zaistenie očkovania, každoročné prehliadky žiakov, hodnotenie duševného vývoja, prospechu a správania žiakov, sledovali chorobnost' školských detí. Pre rekonvalescentov, deti chronicky choré a 
oslabené navrhovali vhodný režim. V spolupráci s hygienikmi evidovali hygienu školského prostredia, úroveň školského stravovania. Po roku 1989 sa vel'a zmenilo aj v poskytovaní zdravotnej starostlivosti. Privatizácia primárnej zdravotnej starostlivosti priniesla možnost' slobodnej vol'by lekára, čo má mnohé pozitíva, ale aj negatíva. Zrušila sa školská zdravotná služba, detskí lekári a sestry prestali vykonávat' už spomínaný zdravotný dozor nad zdravím detí v školách. Súčasné skúsenosti poukazujú na negatívny dopad tohto kroku“ (Boledovičová, Krištofová, Semanišinová, 2006).

Úspešnú sexuálnu výchovu v podmienkach základnej školy by zvládla aj komunitná alebo školská sestra. Na rozdiel od mnohých krajín Európy a USA, kde je v zákone zakotvené aj školské ošetrovatel'stvo, na Slovensku táto aplikovaná ošetrovatel'ská disciplína chýba. V uvedených krajinách je školské ošetrovatel'stvo zamerané na prevenciu a kontrolu prenosných ochorení, zdravotné poradenstvo, podporu zdravia, zabezpečenie a monitorovanie bezpečného a prospešného prostredia, zdravotný manažment a iné (Boledovičová, 2009). Školská sestra, ako odborník voblasti komunitnej starostlivosti pracujúca v školách, je osobou, ktorá prispieva k zlepšeniu duševného a psychického zdravia detí, dôležitú úlohu zohráva aj v prevencii a vo výchove k zdraviu (Paholíková, 2009). Podl’a Boledovičovej, Krištofovej (2007) „školské sestry zaist'ujú primárnu zdravotnú starostlivost' na školách zameranú na udržovanie, zlepšovanie a propagáciu fyzického a psychického zdravia každého školáka v krajine a zaistenie ich emocionálnej a sociálnej prosperity. Plánujú v spolupráci s učitel'mi obsahy kurzov zdravotnej výchovy a výživy a implementujú ich do životov; vykonávajú rutinné zdravotné prehliadky u každého žiaka snadväzným sledovaním detí so zvláštnymi potrebami; sú dôležitými členmi školského zdravotníckeho tímu, v ktorom je riaditel'školy, učitelia, detský lekár, stomatológ, sociálny pracovník, psychológ“.

Schmitt, Gorres (2012) uvádzajú, že školská sestra je kontaktnou osobou pre všetkých zainteresovaných voblasti ochrany a podpory zdravia detí. Jej intervencie smerujú k liečbe akútnych a chronických ochorení v prostredí školy, implementácii preventívnych programov. Poskytuje informácie, pomoc a poradenstvo, posudzuje problémy súvisiace so zdravím.

\section{Ciele}

Ciel'mi prospektívneho výskumu bolo zistit' stanovisko žiakov k zdravotno-výchovným aktivitám v oblasti zdravia, manželstva, rodičovstva a sexuálnej výchovy. Zistit' záujem detí v staršom školskom veku o zdravotno-výchovné a edukačné aktivity v sledovanej oblasti a ich stanovisko na úlohu a postavenie „školskej“ sestry. Zistit’ postoj pedagógov základnej školy na úlohu sestry v školskom prostredí, jej kompetencie a spoluprácu s inými odborníkmi v prostredí základnej školy.

\section{METÓDY}

\section{Výskumný súbor}

Výber výskumného súboru bol zámerný a uskutočnil sa na základe stanovených kritérií. Výskumu sa zúčastnilo 219 žiakov príslušnej základnej školy (126 chlapcov a 93 dievčat), podmienkou bol vek 10-14 rokov. Druhú výskumnú vzorku tvorilo 65 pedagógov (56 žien a 9 mužov). Zarad'ujúce kritérium bolo vyučovanie na základnej škole bez vekového obmedzenia, odborného zamerania, s ochotou spolupracovat'. 


\section{Metodika}

Zber dát vo výskume prebiehal prostredníctvom neštandardizovaného dotazníka vlastnej konštrukcie. Bol určený pre žiakov v staršom školskom veku, obsahoval 23 uzatvorených otázok, v závere jednu otvorenú. Obsahovo boli zamerané na výchovu k zdraviu, manželstvo, rodičovstvo, sexuálnu výchovu, postavenie „školskej“ sestry vo výchovno-vzdelávacom procese základnej školy. Žiaci ho vyplňovali anonymne, dobrovol'ne po súhlase rodičov. Anketa vlastnej konštrukcie s piatimi uzatvorenými otázkami bola určená pedagógom základnej školy na zistenie ich názoru na úlohu sestry v školskom prostredí, jej kompetencie a spoluprácu s inými odborníkmi v prostredí základnej školy. Respondenti hodnotili jednotlivé položky dotazníka na Likertovej škále od 1 do 5 (1- úplne súhlasím, 2 - súhlasím, 3 - neviem, 4 - nesúhlasím, 5 - vôbec nesúhlasím). Zozbierané dáta boli kvantitatívne analyzované s vyjadreným objemom hodnôt premennej x pripadajúcej v priemere na jednu jednotku súboru. Vzájomné vzt’ahy sa verifikovali dvojvýberovým t-testom a Chí-kvadrát testom nezávislosti. Zvolili sme hladinu významnosti $\alpha=0,05$. Výsledky sme vyhodnotili na základe p-hodnoty, čo je pravdepodobnost' nesprávneho zamietnutia nulovej hypotézy o rovnosti stredných hodnôt v prípade dvojvýberového t-testu, resp. nulovej hypotézy o nezávislosti znakov v prípade Chí-kvadrát testu nezávislosti.

Výskum bol realizovaný v regióne Nitrianskeho samosprávneho kraja (d’alej NSK), vo vybranej základnej škole. Dotazníky a ankety boli distribuované osobným kontaktom autorov a sprostredkovanou, poverenou osobou z manažmentu základnej školy.

\section{VÝSLEDKY}

Vúvode realizovaného prospektívneho výskumu všetci respondenti boli oboznámení o problematike sexuálnej výchovy, výchovy k rodičovstvu a o role školskej sestry. Podl'a všetkých žiakov $(M=1,9)$ na realizáciu aktivít v sledovanej oblasti by bola najkompetentnejšia školská sestra, preferovali ju najmä dievčatá, následne priorizovali psychológa (M spolu=2,1). Za najmenej vhodnú osobu pokladali pedagóga $(M=4,2)$.

Očakávali sme, že viac ako polovica žiakov bude považovat’ školskú sestru za vhodného odborníka ako v oblasti sexuálneho zdravia. Na základe štatistického spracovania a pri definovanej hladine významnosti $\alpha=0,05$ sme dospeli k zisteniam. Hodnota testovacej štatistiky dosiahla hodnoty $\chi^{2}=129,337, \mathrm{p}=0,000$. Na základe uvedeného sa nám platnost' hypotézy potvrdila.

Za najdôvernejšiu osobu, s ktorou by sa chlapec vedel porozprávat' so svojimi problémami bol rodič $(M=2,4)$, potom kamarát $(M=2,8)$, psychológ $(M=3,1)$, školská sestra $(M=3,9)$ a sexuológ $(M=4,0)$. Dievčatá uviedli kamarátku $(M=1,9)$, následne rodiča $(M=2,2)$, školskú sestru $(M=3,0)$, psychológa $(M=3,6)$. Žiaci odmietli sa rozprávat's dobrovol'níkom o tejto téme $(M=4,9)$.

Mieru informácií o sexualite, pohlavnom živote, antikoncepcii dievčatá uviedli ako výrazný zdroj kamarátky $(M=1,9)$, sociálne siete $(M=2,1)$, súrodenca $(M=2,3)$, rodiča $(M=2,8)$, literatúru (knihy, časopisy, brožúre, letáky) $(M=3,8)$ a ako posledný bol pedagóg $(M=4,1)$, lekár/sestra $(M=4,9)$. Chlapci získali najviac informácií zo sociálnych sietí $(M=2,3)$, rodičov $(M=3,0)$, kamarátov $(M=3,1)$, súrodencov $(M=3,8)$, literatúry $(M=3,8)$, pedagógov $(M=4,2)$ a ani jeden chlapec neuviedol zdravotníckeho pracovníka.

Prevažná väčšina chlapcov $(M=2)$ aj dievčat $(M=1,6)$ by prijala školskú sestru v rámci organizácie a systému základnej školy a za jej náplň označili chlapci najviac sexuálnu výchovu $(M=2,5)$ a predchádzanie závislostí, prevenciu úrazov, zdravé stravovanie, aplikáciu injekcií a liekov u chronicky chorých žiakoch, prevenciu šírenia infekčných chorôb, podporu emocionálneho zdravia a poradenstvo v dentálnej hygiene $(M=4)$. Dievčatá ako najvýraznejšiu úlohu označili edukáciu a poradenstvo v zdravom stravovaní $(\mathrm{M}=2,8)$, predchádzanie závislostí, sexuálnu 
výchovu, poradenstvo v dentálnej hygiene, prevenciu šíreniu infekčných chorôb, podporu emocionálneho zdravia, prevenciu úrazov, aplikáciu injekcií a liekov $(M=4,1)$ (Tab 2).

Zistili sme, že vedomosti v oblasti sexuálnej výchovy získalo 71,7\% opýtaných detí v staršom školskom veku od rodiča. Ak by bola aktivovaná školská sestra $86,3 \%$, vnímali by ju ako erudovaného odborníka pre edukáciu v oblasti sexuálnej výchovy. 0 skupinové aj individuálne hodiny so školskou sestrou mali porovnatel'ný záujem chlapci $(M=2)$ a aj dievčatá $(M=1,9)$. Respondenti uviedli, že v rámci výchovno-vzdelávacieho procesu na základnej škole bola realizovaná sexuálna výchova zameraná na prevenciu, chlapci $(M=3,9)$ ju pokladali za menej účelovú ako dievčatá $(M=3,3)$. Chlapci $(M=1,8)$ aj dievčatá $(M=1,5)$ mali vysoký záujem o dobrovol'né programy k zvýšeniu vedomostí v oblasti zdravia. Chlapci preferovali edukačné témy zamerané na pohlavný život $(M=1,9)$, sexuálnu výchovu, antikoncepciu, manželstvo, rodičovstvo a rodinu $(M=3,8)$. Dievčatá najviac priorizovali antikoncepciu $(M=1,8)$, sexuálnu výchovu, pohlavný život, manželstvo, rodinu rodičovstvo $(M=3,6)$.

Chlapci $(M=3,1)$ viac boli presvedčení, že školské prostredie je netolerantné voči ich otázkam v oblasti sexuality ako dievčatá $(M=2,8)$. Faktom bola samotná nedostatočná úroveň ich vedomostí, $54 \%$ všetkých respondentov nesprávne definovalo pojem monogamia a za sexuálne prenosné ochorenia pokladali aj ovčie kiahne v 46\%. Z moderných metód ochrany pred nežiaducim otehotnením preferovali chlapci najviac prezervatív 77,7\% a dievčatá hormonálnu antikoncepciu 70,9\%. Predpokladali sme, že oslovení žiaci nebudú mat’ dostatočné vedomosti v oblasti sexuálnej výchovy a zdravia. Predpoklad sa výskumom potvrdil, nakol'ko hodnota testovacej štatistiky bola $\chi^{2}=95,11, p<0,001$. Vedomosti dievčat boli štatisticky významne výraznejšie ako u chlapcov, čo potvrdil aj výsledok testu (Tab 1).

Tab. 1 Významnost' vedomostí dievčat v oblasti sexuálnej výchovy a zdravia

\begin{tabular}{cc}
$\chi^{2}$ & $\mathrm{p}$ \\
\hline 53,55 & $<0,001$
\end{tabular}

Na začiatku výskumu sme predpokladali, že záujem žiakov o zdravotno-výchovné aktivity v oblasti zdravia, manželstva, rodičovstva a sexuálnej výchovy je podmienený množstvom predchádzajúcich informácií. Všetci žiaci, ktorí odpovedali, že ich informácie sú dostačujúce alebo skôr dostačujúce, tiež odpovedali, že majú záujem o dobrovol'né programy k zvýšeniu vedomostí $\mathrm{v}$ oblasti zdravia, sexuálnej výchovy, manželstva a rodičovstva $\left(\alpha=0,05, \chi^{2}=42,988, p=0,000\right)$.

V druhej časti výskumu sa v ankete pedagógovia vyjadrili k záujmu o intervencie školskej sestry, zahrnutie jej pozície do organizácie a systému práce na základnej škole, do výchovnovzdelávacieho procesu žiakov. Zo 65 respondentov 64,6\% malo jednoznačný záujem o prácu školskej sestry a 4,61\% ju odmietlo $(M=1,7)$. Za jej hlavnú činnost' označili prevenciu úrazov $(M=1,2)$, zdravé stravovanie $(M=1,8)$, aplikáciu a podávanie liekov, injekcií chronicky chorým žiakom $(M=2,2)$, sexuálnu výchovu $(M=2,8)$, dentálnu hygienu $(M=3,1)$, prevenciu závislosti $(M=3,3)$, výchovu k rodičovstvu $(M=3,6)$, zodpovednost' za zdravie $(M=4,1)$, prevencia šírenia infekčných ochorení $(M=4,2)$. Podporu emocionálneho zdravia žiakov pokladali za málo významnú činnost' školskej sestry (Tab 2). 
Tab. 2 Významné úlohy školskej sestry (najčastejšie prítomné)

\begin{tabular}{lccc}
\hline Priemer (M) & Dievčatá & Chlapci & Pedagógovia \\
\hline Sexuálna výchova & 3,1 & 2,5 & 2,8 \\
Predchádzanie závislostí & 3,0 & 2,9 & 3,3 \\
Prevencia úrazov & 4,0 & 3,1 & 1,2 \\
Zdravé stravovanie, výživa & 2,8 & 3,2 & 1,8 \\
Aplikácia liekov, injekcií & 4,1 & 3,9 & 2,2 \\
Dentálna hygiena & 3,3 & 4,0 & 3,1 \\
Podpora emocionálneho zdravia & 3,5 & 3,9 & 4,3 \\
Prevencia šírenia infekčných chorôb & 3,5 & 3,7 & 4,2 \\
\hline
\end{tabular}

Pedagógovia uviedli, že najvýznamnejšia spolupráca školskej sestry by bola s pedagógmi $(M=2,5)$, so žiakmi $(M=2,8)$, s rodičmi $(M=3,2)$ a so všeobecným lekárom pre deti a dorast $(M=4,3)$. Na rozdiel žiaci spoluprácu sestry a pedagóga pokladali za menej významnú rovnako u chlapcov aj dievčat $(M=3,8)$ a za najvýznamnejšiu v súčinnosti s nimi chlapci $(M=2,1)$ a dievčatá $(M=1,9)(T a b$ 3).

Tab. 3 Významná spolupráca školskej sestry (najčastejšie prítomné)

\begin{tabular}{lccc}
\hline Priemer (M) & Dievčatá & Chlapci & Pedagógovia \\
\hline Pedagógmi & 3,8 & 3,8 & 2,5 \\
Žiakmi & 1,9 & 2,1 & 2,8 \\
Rodičmi & 2,4 & 3,6 & 3,2 \\
Všeobecným lekárom pre deti, dorast & 3,1 & 2,9 & 4,3 \\
\hline
\end{tabular}

Očakávali sme, že pedagógovia budú mat’ výrazne pozitívnejší postoj k implementácii pozície školskej sestry do organizácie a systému práce, vyučovacieho procesu na základnej škole ako žiaci v staršom školskom veku. Hodnota testovacej štatistiky bola $\chi^{2}=2,58, p=0,108$, predpoklad sme na zvolenej hladine významnosti $\alpha=0,05$ nezamietli, takže sa nepotvrdil. Žiaci aj pedagógovia mali pozitívny postoj k implementácii pracovnej pozície školskej sestry, ale pozorované rozdiely neboli štatisticky významné.

\section{DISKUSIA}

Molčanská, Verbovská (2015) pokladajú sexuálnu výchovu, výchovu k zdraviu za dlhodobý proces. Ak má táto výchova byt’ zmysluplná, musí byt' adekvátne začlenená do rámca globálnej výchovy jedinca $\mathrm{k}$ medzil'udským vzt’ahom. V súčasnom školskom systéme na Slovensku nie je samostatným predmetom. $V$ jednotlivých štátnych vzdelávacích programoch sa v kontexte iba okrajovo nachádza súvislost’ s danou témou, napríklad v 4. ročníku ZŠ v predmete prírodoveda, v predmetoch etická výchova, náboženská výchova, biológia.

V prierezových témach napríklad Osobnostný a sociálny rozvoj, Ochrana života a zdravia s informáciami o reprodukčnom zdraví, vzájomných vzt’ahoch. To kladie na učitel'a vysoké nároky a ak má byt' efektívna, mal by mat' pedagóg dostatočné vedomosti z vedných disciplín súvisiacich s človekom, s jeho sexualitou a vzt’ahmi, adekvátne metodicky zdatný.

Výskumom sme zistili nedostatočné vedomosti žiakov v danej problematike (viac u chlapcov ako dievčat), pokladali prostredie základnej školy za netolerantné voči otázkam v oblasti sexuality a pedagóga nepokladali za odborníka pre výchovu k rodičovstvu a zdravému sexuálnemu životu. 
Morvayová, Gregušová (2006) v obdobnom výskume zistili, že dospievajúce dievčatá mali viac vedomostí $\mathrm{v}$ tejto oblasti ako chlapci. Nemali informácie o riziku sexuálneho zneužívania. Edukáciou v experimentálnej skupine sa výrazne zlepšila úroveň informovanosti o možnostiach antikoncepcie a to najmä u chlapcov, oslabila sa viera dospievajúcich v romantické mýty o fungovaní partnerského vzt'ahu a zvýšila sa informovanost' o riziku sexuálneho zneužívania.

Masaryk (2005) uvádza, že existuje rozpor medzi vnímaním sexuality mladých l’udí a učiteliek/učitel'ov. „Pre žiakov je sexualita najmä o spoznávaní nového a prekonávaní bariér (intrapersonálnych, interpersonálnych, spoločenských). Sex je pre nich prirodzená extenzia priatel'ského vzt'ahu a sympatií, sex je hodnota sama osebe, nie sprievodný jav niečoho iného (napríklad zakladania rodiny)". Na druhej strane učitelia sexualitu vnímali ako súčast' celkových životných rozhodnutí, pevne spätá s rodinou. Výskumom deklaroval, že väčšina pedagógov nereflektovala prenos svojich vlastných konštruktov či presvedčení o tom, čo podl'a nich znamenalo kvalitný život, do obsahu vyučovaných predmetov.

Z výskumu podl'a detí v staršom školskom veku za najmenej vhodnú osobu považovali pedagóga $(x$ 4,2) a za najkompetentnejšiu školskú sestru (x 1,9). Boledovičová, Krištofová (2007) uvádzajú, že „Štandardy praxe školskej sestry“ sa opierajú o ošetrovatel'skú prax, pokladajú ich za vhodný podklad pre rozvoj školského zdravotníctva v podmienkach Slovenskej republiky. „Skvalitnenie zdravotnej starostlivosti je jeho hlavným ciel'om. Samozrejme, že podlieha zmenám a je neustále $v$ štádiu vývoja a zjednocovania. Dokument má dodatok, v ktorom sú obsiahnuté štandardy zamerané na systémy sociálnej služby, interdisciplinárnu spoluprácu, zdravie, teóriu prispôsobenia a výskumu. Ciel'om je zlepšenie systému ochrany zdravia žiakov a rodín, rozvoj vedeckosti vo výskume a zdokumentovanie praxe sestry $v$ škole".

Spoločnost' pre plánované rodičovstvo na Slovensku výskumom u 306 detí v staršom školskom veku z rôznych lokalít Slovenska zistila nedostatočné informácie a vedomosti žiakov najmä v najmä spol’ahlivosti antikoncepčných metód, vedomostiach o rizikovom sexuálnom správaní, ochrane pred sexuálne prenosnými chorobami, sexuálnym násilím a zneužívaním, v poznaní plánovaného rodičovstva, antikoncepcie, sexuálnych a reprodukčných práv, rodových stereotypov a sexuálnej orientácie. Nesprávne a neisté poznanie v otázke sexuálneho agresora malo 34,5\% opýtaných, ohrozenejšie boli dievčatá ako chlapci. Respondenti mali nesprávne vedomosti o homosexualite a netolerantné postoje voči homosexuálom, čo potvrdil aj náš výskum. Zistili sme, že výrazným zdrojom informácií o sexuálnom správaní a zdraví sú sociálne siete a kamaráti, menej rodičia a podl'a opýtaných chlapcov ani raz nemali informáciu od lekára alebo sestry. Zistenia vo výskume Spoločnosti pre plánované rodičovstvo poukázali na „živelné“ alebo vlastnými skúsenost’ami získané informácie, zdroje informácií opýtaných prevažovali priatelia, televízia, časopisy. Výrazne boli ohrozené veriace dievčatá a chlapci, ktoré navštevovali náboženskú výchovu. V záverečnej vol'nej otázke sa niekol'kokrát opakovalo vyjadrenie, že rodičia a učitel' na náboženskej výchove ich obmedzujú v otvorenej komunikácii o sexualite a pohlavnom živote pre ich silné vierovyznanie. Aj Lukšík, Lukšíková (2007) zistili z odpovedí žiakov stereotypy, sexuálna orientácia, plánované rodičovstvo a antikoncepcia. Dôvod uvádzali generačný odstup učitel’ov od žiakov, náboženské dôvody, časové dôvody a nedostatok informácií a materiálov. Opýtané deti v staršom školskom veku zaujímala téma rizikového sexuálneho správania sa. Chceli viac vediet' o pohlavných chorobách, antikoncepcii a jej spol’ahlivosti. Dožadovali sa informácií aj v praktických otázkach o partnerskom vzt’ahu muža a ženy, sexuálneho styku, homosexualite, menštruačnom cykle, anatómii pohlavných orgánov, sexuálne zneužívanie detí v rodine.

Rašková (2013) uvádza názory učitel’ov z pedagogickej praxe, že v súčasnosti sa neuplatňuje sexuálna výchova na základnej škole úplne bez problémov. Učitelia sa nepokladali za odborníkov, lebo neprešli sústavnou sexuálnou výchovou $\mathrm{v}$ systéme školského vzdelávania vrátane vysokoškolskej prípravy na svoje budúce povolanie, mnohí z nich ani v rodine. Učitelia priznali 
absenciu vedomostí, často sa nedokázali odpútat’od rôznych predsudkov, vlastných negatívnych skúseností alebo hanby. Pripúšt'ali negatívne osobné skúsenosti, nevedeli bezprostredne odpovedat' na priame otázky žiaka. Priznali neistotu vo výbere vhodných metód k daným témam, nedokázali často poradit's vymedzením vhodných kl'účových poznatkov pre rozvoj vedomostí, zručností, názorov a postojov voblasti sexuálneho zdravia. Vo výskume sme zistili záujem pedagógov o spoluprácu so školskou sestrou, tak ako to deklarovali aj odpovede žiakov. Významná rola by bola aj v kooperácii s rodičmi a všeobecným lekárom pre deti a dorast. Za hlavnú činnost' školskej sestry označili pedagógovia prevenciu úrazov, zdravé stravovanie, aplikáciu a podávanie liekov, sexuálnu výchovu, prevenciu závislosti, výchovu k rodičovstvu, zodpovednost' za zdravie, prevenciu šírenia infekčných ochorení.

Pozoruhodným zistením bolo, že podporu emocionálneho zdravia žiakov sestrou neoznačil žiadny učitel' napriek tomu, že Schmitt, Gorres (2012) uvádzajú, že školská sestra podporuje zdravý vývoj detí, duševné zdravie a sociálnu klímu v škole, rodine. Rezolúcia Európskeho parlamentu o sexuálnom a reprodukčnom zdraví a právach Odporúča vládam členských štátov, aby vypracovali kvalitnú národnú politiku pre sexuálne a reprodukčné zdravie v spolupráci s občianskymi organizáciami, poskytujúcu detailné informácie o účinných a zodpovedných metódach plánovania rodiny (Lancker, 2002). Vláda žiadneho členského štátu EÚ nemá jasnú a samostatnú politiku pre sexuálne a reprodukčné zdravie, ale väčšina krajín podporuje služby pre plánovanie rodiny, ktoré sú z celkového pohl'adu dobre dostupné v ich zdravotníckych systémoch, najmä prostredníctvom všeobecných lekárov a školských sestier. Tieto služby sú v mnohých krajinách bezplatné. Sexuálna výchova a plánovanie rodiny je integrovanou súčast'ou školského, ale aj zdravotníckeho systému. Akčné programy prijaté na Medzinárodnej konferencii pre populáciu a rozvoj stanovil ako ciel' rok 2015 pre zabezpečenie všeobecného prístupu ku kvalitnej primárnej zdravotníckej starostlivosti vrátane starostlivosti o sexuálne a reprodukčné zdravie. Európske smernice kladú dôraz na zabezpečenie celoživotného vzdelávania zdravotníckych pracovníkov. V koncepčných a strategických materiáloch a právnych predpisoch Slovenskej republiky je celoživotné vzdelávanie povinnost'ou aj sestier. Môže ho naplnit' aj špecializačným štúdiom, ktoré je definované v nariadení vlády SR o spôsobe d'alšieho vzdelávania zdravotníckych pracovníkov. Študijný program Ošetrovatel'ská starostlivost' v komunite etablovaný na Katedre ošetrovatel'stva Fakulty sociálnych vied a zdravotníctva Univerzity Konštantína Filozofa v Nitre zahŕňa v programovej príprave sestier špecialistiek aj oblast’ zameranú na sexuálnu výchovu a formovanie postoja k sexuálnemu života. Obsahovo zameranej na oblast' adolescentov, plánované rodičovstvo, pohlavný život a jeho poruchy, normálne sexuálne správanie ženy a muža, prehl'ad sexuálnych porúch a ich definície, sexuálne prenosné ochorenia v komunite (Akreditačný spis, 2018).

\section{ZÁVER}

Sexuálna výchova musí byt' komplexná a poňatá v širších súvislostiach. Musí zahŕňat' popri získaniu základných vedomostí aj formovanie postoja k sexuálnemu zdraviu, morálke a podpora osobnostnej autonómie mladého človeka a nie len schopnosti uspokojit’ základné, sexuálne potreby. Je dôležité, aby už žiaci základných škôl - deti v mladšom a staršom školskom veku získali kvalitné a plnohodnotné informácie z oblasti partnerských a manželských vzt’ahov, z výchovy k rodičovstvu pred tým, ako sa stretnú s konkrétnymi životnými, spoločenskými, partnerskými situáciami. Zistenia výskumu preukázali, že vhodným odborníkom pre vyplnenie edukačných aktivít voblasti sexuálneho zdravia, výchovy k rodičovstvu by bola práve školská sestra. Jej odbornost' a nezaujatost' v pozícii školského systému by bola prínosom pre riešenie problémov detí, ich rodičov a pedagógov. S ohl'adom na pozitívne medzinárodné skúsenosti, implementácia školských sestier na Slovensku by bola sl'ubným prínosom ako podporovat' zdravie detí s nutným etablovaním špecializačného štúdia na základe medzinárodných učebných osnov pre pozíciu 
školskej sestry a definovaním jej kompetencií.

\section{Etické aspekty a konflikt záujmu}

Autori deklarujú, že štúdia nemá žiadny konflikt záujmu a pri jej spracovaní boli dodržané etické aspekty výskumu. Všetci respondenti boli informovaní o účele výskumu a súhlasili so zaradením do výskumného súboru. Výskum bol schválený manažmentom základnej školy. Na základe ich požiadavky, pred distribúciou bola obsahová štruktúra dotazníka posúdená odborníkom zo psychológie. Najvýraznejšie limitujúcim faktorom bola prítomnost' pedagóga počas vyplňovania dotazníka žiakmi a realizácia výskumu na jednej základnej škole. Výskum nepokrýval reprezentatívne vedomosti o sexuálnom a reprodukčnom zdraví, ale len istú vzorku vedomostných otázok.

\section{Pod'akovanie}

Chceli by sme vyjadrit' pod'akovanie všetkým žiakom, rodičom, pedagógom zo ZŠ v Topol’čanoch, ktorí sa podiel'ali na výskume, a PhDr. Zuzane Sedlárovej za spoluprácu pri vlastnej realizácii výskumu.

\section{LITERATÚRA}

Akreditačný spis schváleného špecializačného študijného programu v špecializačnom odbore Ošetrovatel'ská starostlivost' v komunite. (2018) Nitra : Katedra ošetrovatel'stva, Fakulty sociálnych vied a zdravotníctva UKF v Nitre.

Baker, M. et al., Guiding principles for theprovision and practice. Sexual Health and Blood-Borne Virus Program Communicable Disease Control Directorate Population Health Division Department of Health 2003 [online] [citované 2013-09-12]. http://www.public.health.wa.gov.au.

Boledovičová, M. et al. (2010). Pediatrické ošetrovatel'stvo. Martin: Osveta.

Boledovičová, M. \& Krištofová, E. (2007) School nurse as community nurse working in schools,2007. In: School and Health 21. - Brno : Masarykova univerzita, 2007, p. 509-516.

Boledovičová, M. \& Krištofová, E. \& Semanišinová M.(2006). Školská sestra ako komunitná sestra pracujúca vprostrediach škôl. [citované 2015-11-11]. Dostupné na internete: http://www.ped.muni.cz/z21/2006/konference 2006/sbornik 2006/pdf/051.pdf.

Boledovičová, M. \& Semanišinová M.(2009). Komunitná ošetrovatel’ská starostlivost' v školách. In: Boledovičová, M, Zrubcová, D et al. Sestra a pôrodná asistentka v komunitnej starostlivosti. Nitra : Fakulta sociálnych vied a zdravotníctva UKF; 2009. 153 s.

Bianchi, G. et al. (2000) Integrating quantitative and qualitative HIV/AIDS risk-related research in sexuality: summary of efforts in Slovakia 1993-1997. In: AGGLETON, P. et al. (eds.) AIDS in Europe: new challenges for social and behavioural sciences. London : Routledge, p. 139.

Definitions and Indicators in Family Planning. (1999). Maternal \& Child Health and Reproductive Health Used in the WHO Regional Office For Europe', March 1999.

Hanzlíková, A. et al. (2004). Komunitné ošetrovatel'stvo. Martin: Osveta.

Havlínová, M. \& Kopřiva, P. \& Mayer, I. \& Vildová, Z. et al. (2006). Programypodpory zdraví ve škole. 2. rozš́ŕr. vyd. Praha : Portál. 
Helfferich, C. \& Heidtke, B. (2006). Youth Sex Education in a Multicultural Europe. BZgA / WHO Conference. Cologne / Germany, November 14 th - 16 th , 2006 Country Papers Assessment and report. Commissioned by the Federal Centre for Health Education, BZgA Cologne, October 2006 [online] [citované 2013-09-12]. http://www.sexualaufklaerung.de/cgi-sub/fetch.php?id=489.

Kliment, M. \& et al. (2013). Sexuálne a reprodukčné zdravie v kontexte akčného programu populačnej konferencie Organizácie spojených národov. In: Marková D, Rovňanová L. Sexuality VI - Zborník vedeckých príspevkov. Banská Bystrica: Univerzita Mateja Bela, Pedagogická fakulta, Katedra Pedagogiky; s. 110 - 121.

Lancker, Anne E.M. Správa o sexuálnom a reprodukčnom zdraví a právach. (2001/2128 (INI)) In: Rezolúcia Európskeho parlamentu o sexuálnom a reprodukčnom zdraví a právach (2001/2128 (INI)) 2002. Final A5-0223/2002.

Lukšík, I. \& Lukšíková, L'. (2007) Poznanie žiakov a učitel'ov v oblasti sexuálneho a reprodukčného zdravia. Bratislava: Ústav humanitných štúdií Pedagogickej fakulty Univerzity Komenského v Bratislave.

Lukšík, I. (2005) Poznanie (poznatky) žiakov v oblasti sexuálneho a reprodukčného zdravia a právkvantitatívna analýza (Správa z výskumu). Bratislava: SPR.

Masaryk, R. (2005). Význam konštrukcií kvality života pri vyučovaní výchovy k manželstvu a rodičovstvu. Doktorandská práca. Bratislava: PedF UK.

Molčanská, A. \& Verbovská, J. (2015). Výchova $k$ manželstvu a rodičovstvu $v$ edukačnom procese. Bratislava: Metodicko pedagogické centrum.

Morvayova, D. \& Gregušova, M. (2006). Výchova k partnerstvu a rodičovstvu na ZŠ a SŠ. Bratislava:mn Výskumný ústav Detskej Psychológie a Patopsychológie; 2006. [citované 2015-1111]. Dostupné na internete: https://www.iuventa.sk/sk/Vyskum-mladeze/Vyskumy-katalogdat/2004/Vychova-k-partnerstvu-a-rodicovstvu-na-ZS-a-SS.alej.

Nariadenie vlády SR 296/2010 Z. z. o spôsobe d'alšieho vzdelávania zdravotníckych pracovníkov, sústave špecializačných odborov o sústave certifikovaných pracovných činností v znení neskorších predpisov.

Paholíková, Z. (2009). Úloha školní sestry v systému péče o zdraví dětí. [online] [citované 2009-0912]. Dostupné na internete: http://zdravi.e15.cz/clanek/sestra/uloha-skolni-sestry-v-systemupece-o-zdravi-deti-448612.

Popper, M. \& Bianchi, G. \& Lukšík, I. \& Supeková, M. \& Ingham, R. (2005). The Social Context of Sexual Health Among Young People in Slovakia: Comparisons with the United Kingdom and the Netherlands, In: Sexuality and Gender in Postcommunist Eastern Europe and Russia. - New YorkLondon-Oxford : The Haworth Press, 2005. s. 365-390.

Rašková, M. (2013). Sexuální výchova v edukaci současné české primární skoly. In: Marková, D. Rovňanová, L. Sexuality VI - Zborník vedeckých príspevkov. Univerzita Mateja Bela, Pedagogická fakulta, Katedra Pedagogiky. Banská Bystrica, 2013. 1. Vydanie. S. 260 - 278.

Rovňanová, L. \& Lukšík, I. \& Lukšíková, L'. (2007) Metodická príručka sexuálnej výchovy na druhom stupni základných škôl v rámci učebných osnov výchovy k manželstvu a rodičovstvu. Spoločnost’ pre plánované rodičovstvo. 
Schmitt, S. \& Gorres, S. (2012). School Nursing in Germany? A review about tasks and roles of school nurses]. Schule Gesundheitspflege in Deutschland? Eine Ubersicht Arbeit zu Aufgaben und Rollen von School Nurses. Pflege. 25 (2): 107-117.

Sielert, U. et al. (1994). Sexuální výchova: kniha netradičních metod výuky. Praha: Trizonia.

\section{NURSE ROLES IN SCHOOL SETTINGS}

Abstract: The study objective was to find out the pupils' opinion on health-related educational activities in the areas of health, marriage, parenthood, and sex education. To find out the primary school pupils and teachers' opinions on the role of the nurse in school settings, her competences and cooperation with other professionals. A nonstandardised self-constructed questionnaire was given to 284 respondents. The first sample consisted of 219 pupils aged from ten to 14 years; the second sample consisted of 65 primary school teachers. To analyse the relationships between the responses, we used the two-sample t-test and the chi-square test of independence. Social networks and friends were significant resources of obtaining information for the pupils, and they considered a school nurse an independent, suitable professional for implementation of health education. Both the pupils and teachers were positive about the implementation of the post of school nurse, but the observed differences were not statistically significant $\left(\alpha=0.05 ; \chi^{2}=2.58 ; p=0.108\right)$. The teachers considered the cooperation with the school nurse significant, particularly in prevention of injuries, administration of medicaments to chronically-ill children, and the activities focused on emotional support of health in pupils; however, they considered sex education of little importance. As the most significant roles of the school nurse, the girls selected education and counselling on healthy eating (AM 2.8) and the boys selected sex education (AM 2.5) and addiction prevention. The study supported the significance of the post of school nurse in school settings, for pupils in older school age also in the area of sex education. The teachers perceived the significance of her post in educational activities focused on the areas of general health-related educational prevention.

Keywords: nurse, primary school, nursing, health education, sex education 